\title{
ТЕЗИСЫ ДОКЛАДОВ
}

\section{МЕЖДУНАРОДНАЯ КОНФЕРЕНЦИЯ \\ «Перспективные материалы с иерархической структурой для новых технологий и надежных конструкций»}

\section{Х МЕЖДУНАРОДНАЯ КОНФЕРЕНЦИЯ \\ «Химия нефти и газа»}




\title{
DOI: 10.17223/9785946217408/359 \\ НЕЛИНЕЙНЫЕ ПРОЯВЛЕНИЯ МЕХАНИЧЕСКОГО ОТКЛИКА \\ ФЛЮИДОНАСЫЩЕННЫХ ПОРИСТЫХ МАТЕРИАЛОВ, ОПРЕДЕЛЯЕМЫЕ ВЗАИМОДЕЙСТВИЕМ ТВЕРДОЙ И ЖИДКОЙ ФАЗ
}

\author{
Шилько Е.В., Цуканов А.А., Псахье С.Г.
}

Институт физики прочности и материаловедения СО РАН, Томск, Россия

Известно, что перераспределение жидкой фазы в порах вмещающего твердофазного проницаемого материала оказывает существенное влияние на его динамические физикомеханические свойства. Особое внимание уделяется изучению роли поровых флюидов в поведении хрупких материалов, в первую очередь, горных пород. Влияние процессов перераспределения жидкой фазы на диссипацию упругой энергии во флюидонасыщенных породах определяется как механическим, так и физико-химическим взаимодействием «soft matter - hard matter». Взаимодействие этих компонентов одновременно осуществляется в широком спектре как пространственных масштабов (от наноскопического до макроскопического), так и временных $\left(10^{-9} \mathrm{c}-10^{0} \mathrm{c}\right)$.

В работе представлены результаты теоретического изучения некоторых ключевых аспектов взаимодействия жидкой и твердой фаз, определяющих эффективные механические характеристики флюидонасыщенных хрупких материалов. Исследования проводились путем компьютерного моделирования на нано- и макромасштабном уровнях с применением различных реализаций вычислительного метода частиц.

Рассмотрены особенности структурно-фазового состояния воды в щелевидных нанопорах распространенных природных минералов, таких как гидроксиапатит и «белая ржавчина». Показано, что структура поверхности нанопор и особенности распределения на ней электрического заряда определяют формирование структурированных слоев воды на границе с твердофазной стенкой, которые обеспечивают ярко выраженную селективную проницаемость нанопор по отношению к примесным ионам. Распределение электрического заряда на внутренних поверхностях минералов в значительной степени определяют и физические свойства поровой воды, что особенно ярко проявляется в условиях высоких давлений, реализующихся в нижних слоях земной коры и в верхней мантии. Результаты наномасштабного моделирования свидетельствуют, что распределение заряда на поверхностях пор в породе влияет на изменение объемной жесткости воды (а следовательно, и вмещающей породы) с глубиной и, в том числе, определяет скачки объемной жесткости в точках фазовых переходов и анизотропию сдвигового сопротивления.

Показано, что на макроскопическом масштабе неоднородная диссипация упругой энергии, вызванная фильтрацией жидкой фазы в поровом пространстве, определяет протяженность во времени процессов релаксации напряжений и сильную зависимость макроскопических механических характеристик флюидонасыщенного материала от скорости нагружения. В частности, в условиях монотонного деформирования эффективные упругие модули и прочностные характеристики являются нелинейной логистической функцией (a в ряде случаев - немонотонной функцией в форме суперпозиции нескольких сигмоид) безразмерного числа Дарси. Предложена интерпретация логистического характера этих зависимостей на основе рассмотрения конкуренции процессов деформирования каркаса и перераспределения флюида, определяющих разнонаправленные вклады в изменение объема трещинно-порового пространства. Показана возможность получения единых (калибровочных) кривых, которые позволяют оценивать динамические значения упругих модулей и прочности для различных хрупких флюидонасыщенных материалов и определять неизвестные значения констант влияния флюида на напряженное состояние и прочность этих материалов на основе приведения экспериментальных данных к единой кривой. 